\title{
EMAS in Poland: Performance, Effectiveness, and Future Perspectives
}

\author{
Beata Szyszka, Alina Matuszak-Flejszman* \\ Department of Normalized Management Systems, Faculty of Commodity Science, Poznań \\ University of Economics and Business, Poznań, Poland
}

Received: 6 July 2016

Accepted: 3 October 2016

\begin{abstract}
Our article presents the results of studies on performance and effectiveness of the eco-management and audit scheme (EMAS) system. Therefore, the aim of the article is to analyze the indicators monitored by the EMAS-registered organizations in Poland, to determine the strengths and areas for the implementation of corrective or improvement actions, and to develop recommendations in building effective environmental management systems, monitoring indicators, and revising the EMAS system. The research was conducted in 2013-15 on a group of organizations registered in the EMAS system in Poland. The conclusions of the research enabled us to develop recommendations on potential improvements to EMAS and proposals for amendments while auditing the regulation requirements. The recommendations have been prepared for various interested parties, taking into consideration their competence, powers, and capacity for implementing the suggested actions. These recommendations have been divided into three levels. The first group consists of recommendations at the level of the organization, the second group consists of recommendations at the national level, and the third group are the actions suggested for implementation at the international level.
\end{abstract}

Keywords: environmental management systems, environmental performance indicators, environmental aspects, effectiveness of eco-management and audit scheme, EMAS

\section{Introduction}

Nowadays, one of the biggest challenges that Poland, Europe, and the world have to face is reconciling longterm economic growth with care for the environment. The purpose of improving the quality of life while maintaining the appropriate balance between the three types of capital (economic, social, and natural) requires taking appropriate action at many levels of management. The task of diffusing

*e-mail: alina.matuszak-flejszman@ue.poznan.pl entrepreneurs' sustainable patterns of production, including environmental management systems, is an important element indicated in strategic documents (e.g., Strategy of Energy Security and Environment). Having a look at the trends and strategies related to the necessity of effectively using resources and the need to change production patterns, the implementation of environmental management systems by organizations is inevitable. Especially growing environmental awareness and the pressure on business entities to integrate environmental aspects makes the use of environmentally effective solutions in organizations an essential obligation under the rules of the market. 
The two most popular systems of environmental management are: a system based on the requirements of the international standard ISO 14001 [1] and the system based on the requirements of the regulation of the ecomanagement and audit scheme, or EMAS [2]. EMAS is considered to be more stringent, and the key attributes that have been emphasized in all sorts of marketing campaigns promoting EMAS are "performance," "credibility," and "transparency." The data reported in the EMAS environmental statements has to be verified by an accredited verifier and for that reason, EMAS is considered to be a more effective tool to communicate the environmental aspects to external stakeholders and to improve corporate image [3-6]. Moreover, EMAS also seems to influence innovations. According to Montobbio and Solito [7], EMAS positively affects the number of granted patents (results are particularly strong in low-tech manufacturing and service sectors).

A revision of international standard ISO 14001 was conducted in 2015. Since ISO 14001 is an annex to the EMAS Regulation (Annex II), the changes introduced in this standard impose the necessity of implementing changes in the EMAS system. EMAS was initially adopted by the European Union (EU) in 1993, updated into second revision in 2001, and into the third revision in 2009 [8]. According to information on the European Commission's website, a new regulation will be released in the period between the fourth quarter of 2016 and the first quarter of 2017 [9-11].

The purpose of this article is to analyze the indicators monitored by EMAS-registered organizations in Poland, where the authors tried to determine both strengths and areas for implementation of the corrective or improvement actions. As a result, the authors have worked out recommendations at the organizational, national, and international levels.

\section{Materials and Methods}

The study, the results of which have been described in this article, were carried out in 2013-15. The study consisted of three stages (see Table 1). In order to increase the quality of the study we used triangulation research methods. Triangulation is a combination of different methods during the examination of a single issue in order to increase the amount of gathered information and data value [12]. The study included all organizations registered in the EMAS system in Poland.

In the first stage of the study we used a traditional survey (direct survey methods of collecting data from primary sources) [13-14]. The tool that was used in the study was a survey questionnaire. An electronic questionnaire was applied (CAWI - computer-assisted web interview) as a means of collecting data. Thirty-nine organizations were registered in the EMAS register during the first stage of the studies (access on 2 February 2013) and 26 organizations responded $(\mathrm{N}=39, \mathrm{n}=26$, return $66.7 \%)$.

Secondary sources were used in the second stage of the study. The most important advantage of this study was economizing time and lowering the cost of the research [15]. Secondary data included the EMAS register of organizations and their environmental statements were collected and archived by the General Directorate for Environmental Protection. The second-stage research was conducted on a full basis. The analysis included all 59 EMAS registered organizations.

In the third stage of the study primary data was collected that was used as supplementary data. The data was collected through individual interviews with representatives of EMAS-registered organizations. The study used a structured script. Forty-five organizations were registered in the EMAS register during the third stage of the studies (access on 22 February 2015), and 31 organizations responded $(\mathrm{N}=45, \mathrm{n}=31$, return $68.9 \%)$.

\section{Results and Discussion}

\section{Core Environmental Performance Indicators}

A review of environmental statements in terms of all mandatory indicators was accomplished during the study. Six core indicators of environmental performance were indicated in the EMAS regulation. Core indicators required by EMAS focus on performance in the following key environmental areas [2]: energy efficiency, material efficiency, water consumption, waste generation, biodiversity, and emissions. EMAS provides the possibility not to consider certain indicators in organisations' environmental statements. Any derogation from disclosing indicators may occur if the organization comes

Table 1. Methods of research studies.

\begin{tabular}{|c|c|c|c|c|}
\hline Stage & Type of data & Method & Period & Details \\
\hline Stage 1 & Primary data & $\begin{array}{l}\text { Traditional direct survey } \\
\text { (questionnaire) }\end{array}$ & $1^{\text {st }}$ quarter 2013 & $\begin{array}{c}\mathrm{N}=39 \\
\mathrm{~N}=26 \\
\text { return } 66.7 \%\end{array}$ \\
\hline Stage 2 & Secondary data & $\begin{array}{c}\text { Analysis of environmental } \\
\text { statements }\end{array}$ & $\begin{array}{l}4^{\text {th }} \text { quarter } 2014 \\
1^{\text {st }} \text { quarter } 2015\end{array}$ & $\begin{array}{l}\mathrm{N}=59 \\
\mathrm{~N}=59\end{array}$ \\
\hline Stage 3 & Primary data & $\begin{array}{l}\text { Individual interviews } \\
\text { (structured script) }\end{array}$ & $2^{\text {nd }}$ quarter 2015 & $\begin{array}{c}\quad \mathrm{N}=45 \\
\mathrm{~N}=31 \\
\text { return } 68.9 \%\end{array}$ \\
\hline
\end{tabular}


Table 2. Monitoring core environmental performance indicators by organizations registered in EMAS in Poland (data sources: research studies).

\begin{tabular}{|c|c|c|}
\hline & Area & $\begin{array}{c}\text { Percentage of organisations } \\
\text { that monitor indicators }\end{array}$ \\
\hline 1. & Energy efficiency & $78.0 \%$ \\
\hline 2. & Material efficiency & $71.2 \%$ \\
\hline 3. & Water consumption & $72.9 \%$ \\
\hline 4. & Waste generation & $78.0 \%$ \\
\hline 5. & Biodiversity & $59.3 \%$ \\
\hline 6. & Emissions & $74.6 \%$ \\
\hline
\end{tabular}

to the conclusion that due to the nature of its business one or more of the core indicators is not relevant. A study conducted in 2012 showed that more than one-third of organizations do not reveal comprehensive information on core environmental indicators in their environmental statements [16]. Some of the Polish organizations do not take into account any core indicators in their environmental statements. The averaged results are presented in Table 2.

The biggest number of organizations refrained from disclosing the biodiversity indicator in their reporting. According to the regulation, the indicator is calculated as the "use of land" ratio, expressed in $\mathrm{m}^{2}$ in a built-up area to the total annual output of the organization [2]. Other sources define biodiversity in a much wider perspective. Biodiversity was defined as "the diversity among all living organisms from, inter alia, terrestrial, marine and other aquatic ecosystems and other ecological complexes which they are part of" at the Convention on Biological Diversity at the Earth Summit in Rio de Janeiro [17]. It also concerns diversity within species, between species, and ecosystems [17]. The method of biodiversity rate calculation proposed in the EMAS regulation does not allow for precise deduction and it is difficult to refer to the changes of the indicator rate in a reliable way. Looking at the construction of the indicator, it is not absolutely clear whether by increasing it the organization has achieved a positive or negative environmental effect. Monitoring the percentage of green areas in the total surface area occupied by the organization would seem to be a better solution. However, such a proposal of calculating the indicator would differ from the actual meaning of biodiversity.

Sienkiewicz reviewed the concepts and measures of biodiversity [18]. According to the author, the measures and indicators for biodiversity should monitor the loss rate of natural resources and also the assessment of the effects of inhibitory actions on unfavourable changes. A number of methods of measuring and constructing the indicators for biodiversity assessment have been identified. The analyses are usually based on measures such as richness of species (total number of species), changes in quantitative and qualitative status of species distribution and population size, and the dominance of species (the percentage of the most abundant species) [18]. The construction of recognized biodiversity indicators is based on the numbers of species and number of individuals. However, the 'biodiversity' index suggested in the EMAS regulation is connected with biodiversity merely by a common name. The indicator specified in the regulation does not enable us to assess the natural richness, the variety of life forms, and genetic variability in a proper way.

\section{Other Environmental Performance Indicators}

Analysis of the environmental statements of organizations revealed that $79.7 \%$ of organizations (47 out of 59 subjected to analysis) - apart from the core indicators set in Annex IV of the EMAS regulation as mandatory monitor and report on their environmental statements, also including additional indicators not explicitly included in the requirements of the regulation. Additional indicators monitored by the organizations are often associated with areas of mandatory monitoring (e.g., water, materials), but their calculation formula is different from the one that was indicated in the EMAS regulation. Studies of companies' environmental statements have shown that non-mandatory indicators are mainly related to the operating activities of organizations (41 organizations). The indicators that have appeared the most frequently in environmental statements were those that show the actual impact on the environment against the limit values specified in the environmental agreements and permits. Additional indicators monitored by the organizations are presented in Table 3 .

As shown in Table 3, the non-mandatory indicators, monitored and reported in environmental statements by organizations that have implemented EMAS, apply both to the operating activity of the organization and to management activity. Making a deeper analysis, one might be tempted to further divide indicators into those related to direct environmental aspects and indirect environmental aspects. According to EMAS, an environmental aspect is an "element of an organization's activities, products, or services that has or can have an impact on the environment" [2]. Environmental aspects can be divided into direct ("associated with activities, products, and services over which an organisation has direct management control") and indirect (aspects that "can result from the interaction of an organisation with third parties and which can to a reasonable degree be influenced by an organisation") [2]. Examples of indicators in each group divided by the nature of environmental aspect and type of activity are shown in Table 4.

Taking into account the proposed division, it is not difficult to see that the EMAS regulation in Annex IV describing core environmental indicators requires only monitoring the indicators of group 1 (indicators of operating activities related to the direct aspects). It is an organizational decision whether and to what extent it will monitor additional indicators.

Among the $79.7 \%$ of organizations that monitor additional indicators, the largest part of indicators belongs to group 1 (operating activity related to direct aspects). Such indicators are indicators associated with values obtained 
Table 3. Monitoring of other environmental performance indicators by organizations registered in EMAS in Poland (data sources: research studies).

\begin{tabular}{|c|c|c|}
\hline & Area & $\begin{array}{l}\text { Percentage } \\
\text { of organisations } \\
\text { that monitor } \\
\text { indicators }\end{array}$ \\
\hline \multirow[t]{7}{*}{1.} & $\begin{array}{l}\text { Operating performance } \\
\text { indicators: }\end{array}$ & $69.5 \%$ \\
\hline & $\begin{array}{l}\text { values obtained in relation to } \\
\text { permit limits / environmental } \\
\text { decisions / agreements }\end{array}$ & $49.1 \%$ \\
\hline & $\begin{array}{l}\text { indicators related to waste, } \\
\text { packaging, and by-products } \\
\text { (including recycling) }\end{array}$ & $32.2 \%$ \\
\hline & $\begin{array}{l}\text { measurement of chemical, } \\
\text { physical, and other factors }\end{array}$ & $16.9 \%$ \\
\hline & $\begin{array}{l}\text { indicators related to production } \\
\text { processes }\end{array}$ & $10.2 \%$ \\
\hline & $\begin{array}{l}\text { indicators related to } \\
\text { transportation }\end{array}$ & $6.8 \%$ \\
\hline & $\begin{array}{l}\text { indicators related to the failure } \\
\text { rate of water supply network }\end{array}$ & $5.1 \%$ \\
\hline \multirow[t]{3}{*}{2.} & $\begin{array}{l}\text { Management performance } \\
\text { indicators: }\end{array}$ & $16.9 \%$ \\
\hline & $\begin{array}{l}\text { indicators related to training } \\
\text { courses and environmental } \\
\text { education }\end{array}$ & $15.2 \%$ \\
\hline & $\begin{array}{l}\text { percentage of suppliers holding } \\
\text { ISO } 14001 \text { certificates }\end{array}$ & $3.3 \%$ \\
\hline 3. & $\begin{array}{l}\text { Environmental condition } \\
\text { indicators: }\end{array}$ & $15.2 \%$ \\
\hline
\end{tabular}

in relation to the limits granted in permits / environmental decisions / agreements; the indicators related to waste, packaging, and by-products; the indicators connected with measuring the chemical and physical factors in the workplace; or indicators related to production processes.

The indicators related to transportation may involve both group 1 (operating activity related to direct aspects) and group 3 (operating activity related to indirect aspects), depending on whether they affect a company's own transport or transport of providers and suppliers. In the surveyed organizations, these indicators are related to their own transportation and therefore belong to group 1 .

Indicators related to training courses and environmental education can relate to group 2 (management activity related to direct aspects) as well as group 4 (management activity related to indirect aspects), depending on entities that provide environmental education. In the studied cases, training courses and campaigns were carried out by the organizations; therefore, the indicators belong to direct aspect indicators (group 2).

The indicator related to the percentage of suppliers that hold an ISO 14001 certificate is an indicator of group 4 (management activity related to indirect aspects).

It should be noted that the majority of organizations monitored more than one additional indicator in their environmental statements (a summary of the results is presented in Table 5). The results pertain to the number of organizations that monitor particular types of indicators, and not the quantity of indicators in each group.

Organizations most willingly monitor indicators that illustrate not only the impact on the environment, but that are also useful to determine the degree of fulfilment of legal requirements, or that present potential benefits and savings for the organization. Much of the data available in environmental statements are not gathered for EMAS purposes or for to prepare the environmental statement. The data are analysed mostly because legal regulations of environmental protection require it. EMAS and the process of preparing the environmental statement itself streamlines data collection, which already is (or should be) available in organizations.

Table 4. The division of environmental performance indicators due to the nature of the environmental aspect and type of activity with examples (data source: research studies).

\begin{tabular}{|c|c|c|c|}
\hline & & \multicolumn{2}{|c|}{ Type of activity } \\
\hline & & Operating activity & Management activity \\
\hline \multirow{2}{*}{ 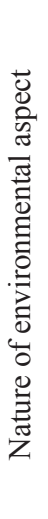 } & 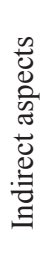 & $\begin{array}{l}\text { Group 3. Indicators of operating activity related to } \\
\text { indirect environmental aspects: } \\
\text { Exhaust emissions and fuel consumption in } \\
\text { suppliers' vehicles } \\
\text { Weight of packaging materials provided by suppliers } \\
\text { Amount and type of chemicals in the composition of } \\
\text { products provided by suppliers }\end{array}$ & $\begin{array}{c}\text { Group 4. Indicators of management activity related to } \\
\text { indirect environmental aspects: } \\
\text { Number of suppliers and subcontractors with an implemented } \\
\text { environmental management system (ISO 14001, EMAS) } \\
\text { Cost savings of the suppliers through the implementation } \\
\text { of environmental initiatives and reduction of resource } \\
\text { consumption }\end{array}$ \\
\hline & 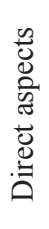 & $\begin{array}{c}\text { Group 1. Indicators of operating activity related to } \\
\text { direct environmental aspects: } \\
\text { Material consumption per unit of product } \\
\text { Use of water or electricity per employee } \\
\text { Concentration of pollutants in waste water } \\
\text { Weight of packaging per unit of product }\end{array}$ & $\begin{array}{l}\text { Group 2. Indicators of management activity related to direct } \\
\text { environmental aspects: } \\
\text { Effectiveness of environmental training courses and } \\
\text { emergency exercises } \\
\text { Response time to environmental incidents } \\
\text { Cost savings from pro-environmental investments }\end{array}$ \\
\hline
\end{tabular}


Table 5. The indicators monitored by organizations due to the nature of the environmental aspect and type of activity (data source: research studies).

\begin{tabular}{|c|c|c|c|}
\hline & & \multicolumn{2}{|c|}{ Type of activity } \\
\hline & & $\begin{array}{c}\text { Operating activity } \\
41 \text { organizations } \\
69.5 \%\end{array}$ & $\begin{array}{c}\text { Management } \\
\text { activity } \\
10 \\
\text { organizations } \\
16.9 \%\end{array}$ \\
\hline 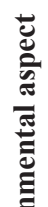 & 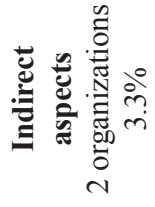 & $\begin{array}{c}\text { Group } 3 . \\
0 \text { organizations } \\
0.0 \%\end{array}$ & $\begin{array}{c}\text { Group } 4 . \\
2 \text { organizations } \\
3.3 \%\end{array}$ \\
\hline 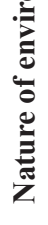 & 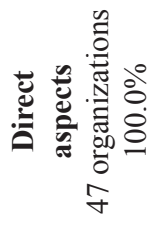 & $\begin{array}{c}\text { Group 1. } \\
41 \text { organizations } \\
69.5 \%\end{array}$ & $\begin{array}{c}\text { Group } 2 . \\
9 \text { organizations } \\
15.2 \%\end{array}$ \\
\hline
\end{tabular}

Both core environmental indicators required by EMAS and additional indicators monitored by the organizations concern mostly operational activity of the organization and are related to direct environmental aspects. Such an approach is a significant limitation. The objective of EMAS was to influence far beyond the registered organizations, which should be obtainable through monitoring of indirect environmental aspects. Managing indirect environmental aspects should be reflected in the monitoring of environmental indirect indicators. The results of core indicators required by EMAS are not reliable in relation to the actual impact of the organization, where the direct environmental aspects were not considered as significant because in that case indicators are usually associated only with running the office. These organizations include public administration institutions and organizations dealing with waste collection, disposal, and recycling. This group of organisations is the largest among those registered in EMAS [11]. Consequently, the service organizations usually resign from calculating core environmental indicators (which is acceptable in EMAS), and calculate indicators determined individually. As a result, it becomes impossible to make comparisons - even between organizations operating in the same sector.

The resignation of management indicators also has its drawbacks. Studies indicate that the integration of environmental objectives with the strategy of the organization is a key factor in building effective management systems [19]. Meanwhile, many organizations are driven by a short-term orientation while advantages of investments generally have long-term payoff [20].

The intention of the study is not to depreciate the role of operational indicators associated with direct environmental aspects, but it aims to illustrate the obvious disproportion between monitoring different groups of indicators. Operating indicators play an important role in an environmental management system. Although in order to obtain a wider perspective it is not worth resigning from monitoring other types of indicators. The indicators from different groups should be monitored to maintain balance. In particular, it is advisable to monitor the indicator of the amount of subcontractors and suppliers with an implemented environmental management system. Other indicators of business management that may be considered by organisations are indicators of the effectiveness of training courses, emergency exercises, response time to environmental incidents, and savings from the reduction of the consumption of resources and the implementation of initiatives and pro-environmental investments.

To summarize this part of research, the indicators should relate to both operational and managerial activities. They should also be related to direct and indirect environmental aspects. The indicators should be determined more precisely in such a manner that it would be possible to make comparisons between them. The current EMAS regulation gives far too much freedom to choose alternatives to calculate indicators in different areas. Indicators can be calculated in relation to the total annual impact, the number of employees, per unit of production in relation to gross value added, or even man-hours. Such freedom, as a consequence, makes it difficult to compare organizations - even those operating in one sector. The solution would be to develop guidelines for the calculation of indicators for each sector (under one code of NACE). According to authors, indicators relevant to one sector can be unsuitable in other sectors. First of all, the sectors most strongly represented in EMAS (public administration and waste collection, processing, disposal, and recycling) should be focused on indirect indicators. An additional benefit could be global monitoring and comparing the organizations in the sector classification. Such comparisons would make organizations focus on achieving positive environmental effects more willingly and they would also provide a basis for building the credibility of EMAS toward banks and insurance companies.

A summary of the best environmental management activities, sectoral indicators of environmental performance efficiency, and criteria of excellence for different industries are presented in reference documents (BEMP, or best environmental management practices). Such a document has been issued so far only for the retail sector (draft documents prepared for the sectors of tourism, construction, public administration, agriculture, food, and non-alcoholic beverages, electrical and electronic manufacturing, the automotive industry, and the waste management and telecommunications sectors). The reference documents do not limit the option of calculating the core indicators, but they contain a summary of additional sectoral indicators.

\section{Mistranslation in EMAS Regulation}

EMAS Regulation was amended twice, but still many issues remain incorrectly defined or unjustified. This 
Table 6. Recommendations (data source: research studies).

\begin{tabular}{|c|c|}
\hline \multicolumn{2}{|r|}{ Recommendations at the organizational level } \\
\hline 1 & $\begin{array}{l}\text { It is advisable to pay more attention to the accuracy of the records when setting environmental objectives. Properly set goals } \\
\text { must be clearly defined and the expected value must be indicated. The objectives should be defined in accordance with the } \\
\text { SMART principle (specific, measurable, ambitious, realistic, time-bound [24]). }\end{array}$ \\
\hline 2 & $\begin{array}{l}\text { The environmental objectives must be clearly separated from resources and measures to achieve them (measures to achieve } \\
\text { objectives and implementation of the tasks cannot be stated as an environmental objective itself). In many cases, organizations } \\
\text { have set as a target training courses. However, it should be emphasized that a training course is a tool to achieve the objective, } \\
\text { e.g., in the case of improving employee environmental awareness. }\end{array}$ \\
\hline 3 & $\begin{array}{l}\text { Due to the fact that transparency is one of the key principles of EMAS, full analysis of the reasons for not achieving the envi- } \\
\text { ronmental objectives should be disclosed in environmental statements. In many cases, organizations inform only about aims } \\
\text { achieved and about the objectives that were not achieved in a very limited way. This certainly plays a significant role in assess- } \\
\text { ing environmental performance of an organization and is one of the EMAS requirements. }\end{array}$ \\
\hline 4 & $\begin{array}{l}\text { Establishing environmental objectives compatible with the strategic plans of the organization, as well as those connected with } \\
\text { an increase in market share, are considered to be good practice. The integration of environmental objectives with the strategy of } \\
\text { the organization plays a significant role and gives the ability to achieve better results. }\end{array}$ \\
\hline 5 & $\begin{array}{l}\text { It is advisable to take into account reference documents BEMP in the environmental statements in a wider approach. These } \\
\text { documents constitute significant information on key environmental aspects in specific sectors. Despite the fact that some of the } \\
\text { documents are still in draft form, the process is at such an advanced stage that it is recommended to use them in the develop- } \\
\text { ment of environmental statements. }\end{array}$ \\
\hline 6 & $\begin{array}{l}\text { It is good practice to set environmental objectives to be achieved under specific areas in such a way as progress would be } \\
\text { presented in the environmental statements. Then the information contained in environmental statements would be more legible } \\
\text { and connected with the significant environmental aspects with environmental objectives, and key indicators and the effects of } \\
\text { environmental performance will be more clear. }\end{array}$ \\
\hline 7 & $\begin{array}{l}\text { Greater integration of EMAS with supply-chain management is recommended. The environmental aspects must be taken into } \\
\text { consideration while selecting and evaluating the suppliers. It should also be a useful tool for monitoring the number of suppliers } \\
\text { that have already implemented an environmental management system such ISO } 14001 \text { and EMAS. }\end{array}$ \\
\hline 8 & $\begin{array}{l}\text { Organizations are encouraged to apply to a wider range the utility of the ISO } 14000 \text { series standards (e.g., } 14031,14015 \text {, } \\
\text { 14051). These standards contain a valuable source of knowledge and are the best available practices in environmental manage- } \\
\text { ment generated at an international level. }\end{array}$ \\
\hline \multicolumn{2}{|r|}{ Recommendations at the national level } \\
\hline 1 & $\begin{array}{l}\text { It is postulated that a system of measurable incentives and benefits to EMAS-registered organizations should be developed } \\
\text { (including tax allowances, lowering environmental fees, reducing the frequency and simplification of inspection by law-en- } \\
\text { forcement bodies, accelerating and facilitating the issuing of permits and environmental decisions). Although with } 68 \text { registered } \\
\text { organizations Poland ranks sixth in the number of organizations registered in EMAS, compared to the more than } 2,500 \text { organi- } \\
\text { zations certified for compliance with the requirements of ISO 14001, this still represents a very small percentage. }\end{array}$ \\
\hline 2 & $\begin{array}{l}\text { Cooperation with the insurance industry in order to increase knowledge of EMAS by insurers may result in the reduction of } \\
\text { insurance rates for EMAS-registered organizations and become an important stimulus for the implementation of EMAS. }\end{array}$ \\
\hline 3 & $\begin{array}{l}\text { It is suggested that promotional activities of EMAS taking into consideration the activities referred to in articles } 34-38 \text { of the } \\
\text { EMAS Regulation be strengthened. }\end{array}$ \\
\hline \multicolumn{2}{|r|}{ Recommendations at the international level } \\
\hline 1 & $\begin{array}{l}\text { During the revision of the EMAS regulation and the introduction of future revisions, it is necessary to standardize concepts and } \\
\text { pay more attention to the correctness of the referenced definition and the correctness of translations. }\end{array}$ \\
\hline 2 & $\begin{array}{l}\text { It is necessary to change the structure of biodiversity indicators, which in its present form does not allow for precise conclu- } \\
\text { sions. }\end{array}$ \\
\hline 3 & $\begin{array}{l}\text { It is suggested to review core environmental performance indicators in such a way that the indicators would refer both to direct } \\
\text { and indirect environmental aspects. In its present form, the indicators refer only to direct environmental aspects. }\end{array}$ \\
\hline 4 & $\begin{array}{l}\text { It is to review core environmental performance indicators in such a way that the indicators would refer both to evaluation of } \\
\text { operating activities and management activities. In its present form, the indicators focus solely on assessing operational activity. }\end{array}$ \\
\hline 5 & $\begin{array}{l}\text { In order to increase the comparability of the data, it is suggested to narrow the choice of options for calculating the indicators in } \\
\text { specific areas through the development of guidelines for monitoring indicators in various industries (taking into account NACE } \\
\text { codes). }\end{array}$ \\
\hline 6 & $\begin{array}{l}\text { In order to increase pressure on achieving positive environmental effects and to build the credibility of EMAS for banks and } \\
\text { insurance companies, it would be beneficial to create rankings in specific sectors. }\end{array}$ \\
\hline
\end{tabular}


Table 6. Continued.

\begin{tabular}{|c|c|}
\hline 7 & $\begin{array}{c}\text { It is postulated that a partnership with the insurance industry to adapt the information required by EMAS to the information } \\
\text { needs by insurers should be launched. Currently, insurers rarely treat environmental management systems as a direct basis for } \\
\text { lowering the rates of insurance premiums, treating environmental management systems rather as a tool to minimize the risks } \\
\text { that may indirectly affect the amount of insurance rates [Atwell 2004]. However, in terms of the effectiveness of environmental } \\
\text { risk management, the most desirable model would be to establish a relationship in which environmental risk insurance would } \\
\text { complement implemented environmental management systems (creating a mutually complementary relationship). This will } \\
\text { be possible only if the environmental management systems will be better known in the insurance sector and the information } \\
\text { required by these systems and generated by the organizations will be more adapted to the information needs of insurance com- } \\
\text { panies [25-26]. }\end{array}$ \\
\hline 8 & $\begin{array}{c}\text { It would be beneficial to intensify the study on the sectoral reference documents. The commission communication of } 2011 \\
\text { described the indicative list of } 11 \text { priority sectors, whereas a reference document for only one sector has been officially released. }\end{array}$ \\
\hline
\end{tabular}

should be taken into account during the next revision of the regulation. One of the objectives of the recent amendment of the EMAS regulation was to influence beyond the registered organizations. It should happen due to the introduction of a requirement that the registered organizations were to take into account the environmental aspects when selecting suppliers and service providers. This requirement was not defined precisely enough. The regulation uses the term "procurement," which seems to be controversial. It is not clear whether it concerns only public procurement (which would indicate that it only applies to public finance sector entities), or it refers to contracts in the general meaning of this word. The dispute is compounded by the fact that the requirement was incorrectly translated from the original version into the Polish language. Consequently, in the Polish version organizations are obliged to identify environmental aspects associated with their own "procurement procedures." However, the "original" requirement is not limited only to public procurement, but procurement / purchasing / acquisition in the general meaning of this word (in the English version "procurement" is a synonym for the word "purchasing," and not "public procurement").

As far as the translation is concerned, in the Polish version of the regulation the phrases "environmental performance indicators" as "efektywność środowiskowa" and "performance" as "efektywność" were mistranslated. Unfortunately, the phrases "effectiveness, efficiency, performance, capability" in everyday language are often used interchangeably, often incorrectly as synonyms, which in turn makes the meaning of these terms not accurate enough. "Efektywność (efficiency)," in contrast to other phrases, refers to the achievement of the objectives while taking into account the size of the necessary expenditures (the ratio of the effects to the resources used). The expenditure can be money spent, effort, time, etc. "Environmental performance indicators" should be identified with "effectiveness" (not efficiency), because their calculation formulas in no way take into account the expenditure incurred and resources for achieving the results, but only the degree of implementation of the environmental objectives. In the present form, the core indicators have little to do with the idea of ecoefficiency, since they are focused on the effect but not on assessing the factor connected with expenditures [21].
Apart from the translation of the word "performance," the interpretation of the word "efficiency" has caused the trouble. Inconsistency in this matter is objectionable. "Efektywność energetyczna" is a Polish translation of "energy efficiency," "efektywne wykorzystanie materiałów" for "material efficiency," and "sprawne działanie rynków" is a translation of "the efficient operation of markets." It is necessary to standardize the terms and pay greater attention to the correctness of the referenced definition and the correctness of translation while reviewing EMAS and introducing future revisions. The EMAS regulation in its current form does not require taking into account the costs and expenses incurred in order to achieve its objectives, and therefore the word "efficiency" should not be used at all.

\section{Recommendations}

Research studies have shown that operating EMAS in Poland has appeared to be disappointing in many cases [22]. Unfulfilled expectations concern mainly financial and economic aspects (no tax relief and reduction of insurance rates, no influence on environmental fees, no priority in obtaining grants and subsidies). Representatives of organizations expect marketing and promotional benefits (boosting recognition of the benefits connected with EMAS for the public and customers) and the advantages connected with administrative and audit activities (e.g., decrease in frequency of inspections carried out by law enforcement authorities, the simplification of control procedures, speeding up the process of official cases [23]. Therefore, more emphasis should be put on support for the organizations that are interested in the implementation, maintenance, and improvement of EMAS systems.

The research study has allowed us to develop recommendations for potential improvements of EMAS. Recommendations have been prepared for different groups, depending on their competences, authority, and implementation possibility. Recommendations are based on research results and are divided into three levels: organisational, national, and international (Table 6). At the organizational level recommendations are aimed at building effective management systems. At the national level recommendations include implementing benefits for EMAS-registered organisations. Recommendations 
suggested at the international level are related to monitoring indicators and revising EMAS regulations.

\section{Conclusions}

Although EMAS regulation has been amended twice, many issues still require improvements. First of all, some indicators like biodiversity are constructed in an inappropriate way. The regulation does not give a definition of biodiversity, but only provides a formula for calculating the indicator. The structure of biodiversity indicator is usually based on measures such as species richness, quantitative and qualitative changes status of species distribution and abundance of animals, and the dominance of species (the percentage of the most abundant species). However, the "biodiversity" indicator proposed in EMAS is connected with "true" biodiversity only by a common name. The EMAS indicator does not allow in any way the correct assessment of natural riches and the variety of life forms, and the genetic variation and form of the indicator does not allow for clearly assessing whether an organization has achieved positive or negative environmental effects by increasing or decreasing indicator rates.

Other core indicators used in EMAS more property reflect the actual state of the organization. However, these indicators do not reflect the idea of eco-efficiency because the method for calculating them does not take into account factors related to the expenditures incurred. It is important to remember that there could be some individual factors that the organization is unable to predict or control and which might play an important role (e.g., the value of energy efficiency indicator is highly dependent on the time of year and annual temperatures, which influence the length of the heating season, the amount of time spent while working under artificial lighting, using air conditioning during the summer, etc.). Moreover, it might seem to be difficult to reflect on the actual environmental influence of the organization on the environment using the given indicators. Water and electricity consumption in service organizations, where the consumption does not depend solely on the number of employees but also on the number of customers, could be an example.

EMAS gives the possibility to choose too many options to calculate indicators in different areas. As a result, such flexibility makes it difficult or even impossible to compare organizations - even those operating in the same sector. It would be useful to develop guidelines under which individual organizations within the same industry (one NACE code) would be required to count the indicators in the same standardized manner. The results of individual organizations could then be monitored globally and compared with one another in rankings within particular sectors. Such comparisons would increase pressure to achieve positive environmental effects, and would give a basis for building the credibility of EMAS toward banks and insurance companies. The compilation of sectoral environmental performance indicators for specific sectors has been developed in reference documents (BEMP). These documents, however, do not restrict method choices for calculating core indicators; instead, they include the compilation of additional sectoral indicators. Environmental indicators often merge into one another and affect each other. Improving environmental performance in one area often affects the deterioration of environmental performance in another area (e.g., extension of the installation has a negative impact on the reduction of green areas, the necessity to maintain green areas results, in turn, in higher water consumption, especially in the summer months).

The core environmental performance indicators identified by EMAS relate only to direct environmental aspects. Organizations in which the direct environmental aspects were not considered as significant show the results of indicators that cannot be considered as measurable in relation to the real environmental impact, since they are usually connected only with running the office. Organizations often report these indicators knowing that the environmental impact resulting from direct environmental aspects is minor. However, indirect environmental aspects and ways of managing them are of paramount importance.

The core environmental performance indicators relate only to the assessment of the effects of operating performance; they do not apply to the evaluation of management performance. Environmental management systems carried out only at the operational level are often insufficiently related to strategic planning and, consequently, the activities carried out in the environmental area are often ineffective [27-28]. Proper strategic planning and integration of environmental objectives within the strategy of the organization is a key factor in building effective management systems [19]. ISO 14001:2015 requires the integration of environmental aspects into strategic planning [1]. Hence, the next edition of the EMAS regulation should also take into account issues connected with the involvement of management and the inclusion of management performance indicators in planning the environmental performance of the organization. The implementation of EMAS is not a turning point in an organization's strategy on the protection of the environment. It is only a step forward in the process of gradual improvement of environmental management [29] and achieving environmental effects in this area.

In order to improve EMAS, system recommendations that have been determined through research should be considered by organisation representatives, local authorities, national competent bodies, and the European Commission during revision of the regulation. As such, this paper should be of interest to a broad readership, including those interested in original research papers, research, and policy reviews. This paper covers environmental issues of international significance and of international relevance. 


\section{Acknowledgements}

This paper is based on the results of the research project "Research on the effectiveness and efficiency of the Eco-Management and Audit System in companies on Polish territory." The project was financed by the National Science Centre granted pursuant to decision No. DEC2012/07/N/HS4/02654.

\section{References}

1. EN ISO 14001:2015, Environmental management systems Requirements with guidance for use. 2015.

2. Regulation (EC) No 1221/2009 of the European Parliament and of the Council of 25 November 2009 on the voluntary participation by organizations in a Community ecomanagement and audit scheme (EMAS), repealing Regulation (EC) No 761/2001 and Commission Decisions 2001/681/EC and 2006/193/EC. 2009.

3. TESTAF., RIZZIF., DADDIT., GUSMEROTTIN.M., FREY M., IRALDO F. EMAS and ISO 14001: the Differences in Effectively Improving Environmental Performance. Journal of Cleaner Production. 68, 165, 2014.

4. IRALDO F., TESTA F., FREY M. Is an Environmental Management System able to Influence Environmental and Competitive Performance? The Case of the Eco-management and Audit Scheme (EMAS) in the European Union, Journal of Cleaner Production. 17 (16) 1444, 2009.

5. ARIMURA T., HIBIKI A., KATAYAMA H. Is a voluntary approach an effective environmental policy instrument? A case for environmental management systems. Journal of Environmental Economics and Management. 55, 281, 2008.

6. IRALDO F., LANZINI P., MELIS M. How does EMAS Affect Organizations' Effort and Competitive Rewards? Analysis of the Drivers, Barriers and Benefits Connected with the EU Scheme, IEFE Centre for Research on Energy and Environment Economics and Policy. Boccioni University. Milano. January 2010.

7. MONTEBIO F., SOLITO I. Does EMAS foster innovation in European firms? An empirical investigation. SEEDS Working Paper 16/2015 September 2015.

8. TOURAIS P., VIDEIRA N. Why, How and What do Organizations Achieve with the Implementation of Environmental Management Systems? Lessons from a Comprehensive Review on the Eco-Management and Audit Scheme. Sustainability. 8, 283. 2016.

9. http://ec.europa.eu/environment/emas/pdf/factsheet/ EMASiso14001_high.pdf

10. http://ec.europa.eu/environment/emas/pdf/factsheet/ EMAS_revised_ISO14001.pdf

11. www.ec.europa.eu

12. KACZMAREK M., OLEJNIK I., SPRINGER A. Qualitative research. Methods and applications, CeDeWu, Warsaw, Poland. 2013.

13. KACZMARCZYK S. The application of marketing research. Marketing management and enterprise environment, PWE, Warsaw, Poland. 2007.
14. KACZMARCZYK S. Marketing Research. Methodical base, Polish Economic Publishing House, Warsaw. 2011.

15. CHURCHIL G.A. Marketing research. Methodological basis, PWN, Warsaw. 2002.

16. SKOULOUDIS A., JONES K., SFAKIANAKI E., LAZOUDI E., EVANGELINOS K. EMAS statement: Benign accountability or wishful thinking? Insights from the Greek EMAS registry. Journal of Environmental Management. Vol. 128, 1043-1049. 2013.

17. The Convention on Biological Diversity, dated. June 5 In 1992, signed in Rio de Janeiro (Journal of Laws of 2002 No. 184, item.1532).

18. SIENKIEWICZ J. Concepts of biodiversity - their dimensions and measures in the light of literature, Environmental Protection and Natural Resources, No. 45, 2010.

19. DEL BRIO J.A., FERNANDEZ E., JANQUERA B., VAZQUES C.J. Motivations for Adoptingthe ISO 14001 Standard: A Study of Spanish Industrial Companies, Environmental Quality Management, 10 (4), 13, 2001.

20. HERAS-SAIZABITOIA I., BOIRAL O., ARANA G. Renewing environmental certification in times of crisis. J. Clean. Prod. 115, 214-223. 2016.

21. ERKKO S., MELANEN M., MICKWITZ P. Eco-efficiency in the Finnish EMAS Reports - a Buzz Word?, Journal of Cleaner Production, 13 (8), 799, 2005.

22. SZYSZKA B., MATUSZAK-FLEJSZMAN A. EMAS unfulfilled expectations and challenges associated with the planned publication of the new ISO 14001:2015, Sustainable Development, WIT Transactions on The Built Environment, 168, 2015.

23. SZYSZKA B., MATUSZAK-FLEJSZMAN A. Barriers and unfulfilled expectations related to the implementation EMAS, Skrzypek E. (ed.), Quality as a success factor in the new economy, Publisher of Marie Curie Sklodowska (UMSC) in Lublin, Lublin. 2014.

24. DAY T., TOSEY P. Beyond SMART? A new framework for goal setting, The Curriculum Journal, 22 (4), 2011.

25. LEMKOWSKA M. Environmental Management System ISO 14001:2004 and the environmental risk insurance An attempt to assess the relationship, Scientific Books, Publishing Poznan University of Economics, No. 166, Poznan. 2011.

26. LEMKOWSKA M. The role of insurance in indemnifikation anainst primary environmental damage, Economics and Environment, No. 2 (53), 2015.

27. FIGGE F., HAHN T., SCHALTEGGER S., WAGNER M. Sustainability Balanced Scorecard, Lüneburg, CSM. 2001.

28. FIGGE F., HAHN T., SCHALTEGGER S., WAGNER M. The Sustainability Balanced Scorecard - Theory and Application of a Tool for Value-Based Sustainability Management, Centre for Sustainability Management, Conference „Corporate Social Responsibility - Governance for Sustainability”, Gothenburg. 2002.

29. DADDI T., MAGISTRELLI M., FREY M., IRALDO F. Do Environmental Management Systems Improve Environmental Performance? Empirical Evidence from Italian Companies, Environment, Development and Sustainability, 13 (5), 845, 2011. 